Wacana Vol. 13 No. 2 (October 2011): 233-255

\title{
Ethnicity and the performance of identity
}

\author{
MANNEKE BUDIMAN
}

\begin{abstract}
This essay looks into the novels of two Indonesian women writers, Perempuan Kembang Jepun (Lan Fang 2009) and Dimsum terakhir (Clara Ng 2006), which depict the struggles of the major female characters in negotiating their "hybrid" identities amidst the pulls from various opposing forces that try to impose and define their identities. Both works were published in the post-New Order Indonesia, where identity politics seems to dominate the political and cultural realms. Both Lan Fang and Clara Ng try to problematize the rigid and monolithic sense of cultural identity that had been inculcated by the previous regime through its aggressive assimilation policy and imposition of the state ideology of unity. The essay aims at examining different strategies employed by both authors in redefining identity through approaches that see identity as a fluid, non-essentialist, and on-going process rather than a given entity or label that can be simply inscribed on individuals.

KEYWORDS

Women writers, cultural identity, post-New Order Indonesia.
\end{abstract}

\section{INTRODUCTION}

As a post-colonial nation consisting of over three hundred indigenous ethnic groups, Indonesia has witnessed a series of ethnic conflicts and tensions during the six decades since independence from colonial powers. Ethnic conflict is especially rife since the Reformasi of 1998 as a result of the loosening grip of a central government that had been authoritarian in nature for over thirty years. As the country's economy crumbled in 1997-1998, the Suharto regime lost its political legitimacy, and demands for more autonomy in the provinces could no longer be ignored. Ethno-nationalist sentiments that were dormant for years were reawakened during the tumultuous first five years of the Reformasi, as became apparent in several violent conflicts between various ethnic groups,

MANNEKE BUDIMAN teaches literature and cultural studies at the Faculty of Humanities, University of Indonesia. He was trained in English Literature, Comparative Literature, and Asian Studies. He also teaches at the Graduate Program of Urban Studies, the Jakarta Institute of the Arts. He serves at the editorial boards of some scholarly journals, including Jurnal Ilmu Sastra dan Budaya SUSASTRA and Jurnal Lintas Bahasa TRANSLINGUA. In addition, he is currently Series Editor for Kota, Kata dan Kuasa (Ombak Press). Manneke Budiman may be contacted at manneke.budiman@gmail.com.

(C) 2011 Faculty of Humanities, University of Indonesia 
especially on the islands of Kalimantan and Ambon, as well as in the capital city of Jakarta where people from different ethnic backgrounds coexist in at times uneasy relationships. West Kalimantan was devastated by a bloody conflict between the Dayaks, Malays, and Madurese between February and April 2001; Ambon was ripped apart by what seemed to be a religious conflict between Muslims and Christians from 1999 to 2001, though it actually was as much an ethnic conflict as it involved the Ambonese, Buginese, and Javanese. Jakarta, as the main hub of the country, is not an exception as the native Betawis have been involved in a series of clashes with Madurese migrants. To discuss the genealogies of these conflicts would be too complex an endeavor: suffice it to say that, despite the severity of the conflicts and their prolonged impact on the sense of unity of the nation, it is remarkable that Indonesia has survived potential balkanization such as in the former Soviet Union and the Balkan states. The history of ethnic violence in the archipelago, however, dates far back to the colonial period, especially where the ethnically different Chinese group is concerned.

The first and most significant massacre of Chinese in the archipelago during Dutch rule took place in 1740, when thousands of Chinese in Batavia (the colonial name of Jakarta) were killed by the Dutch. ${ }^{1}$ Violence against the Chinese also occurred during the Java War (1825-1830) between the Dutch and the Javanese sultanate of Yogyakarta, in the period of Revolution between 1945 and 1949. It continued throughout the 1950s as a result of the repatriation policy issued by Soekarno's administration, and also between 1965 and 1966 after the failed coup attempt by the communists. ${ }^{2}$ The Chinese were seen by the New Order regime as a potential threat to its anti-communist ideology. Suharto, in his efforts to solve the so-called "Chinese problem", issued a strongly assimilationist law in 1967 that prohibited any practices related to Chinese culture. ${ }^{3}$ Although the pretext of the law was to accelerate the assimilation of the Chinese into Indonesian society, in reality the Chinese continued to be considered as "non-indigenous citizens" (bukan warga asli), and therefore hostility towards them never really ceased to exist, particularly since the Chinese in general have excelled in economic achievements. ${ }^{4}$

On 15 January 1974, a protest that was initially directed against the domination of Japanese investment over local businessnes turned into an anti-Chinese riot as mobs burnt and ransacked Chinese stores in Glodok and Senen areas. The most recent incident occurred in May 1998, at the brink of a momentous political shift of power, when hundreds of Chinese women were reportedly raped, and rioters looted and burned hundreds of shops and buildings belonging to Chinese residents. What has not always been fully realized is that most of the prominent Chinese businesses in Indonesia are

1 The Dutch colonial period in the archipelago officially began in 1800, but the Dutch East India Company (VOC) had already had control of the region since 1602 until its bankruptcy in 1800, when the Dutch government in the Netherlands took control.

See Lohanda (2002) "Masalah Cina".

Lohanda 2002: 68-69.

Lohanda 2002: 70-71. 
owned by totok (full-blood) Chinese, the "less-assimilated recent immigrants", yet anti-Chinese sentiment is often extended to peranakan Chinese, whose ancestors have lived in Indonesia for generations and who are therefore more assimilated. Most peranakan Chinese own smaller businesses and enjoy less protection from the government. ${ }^{5}$ There is a wide consensus among scholars that the 1998 outbreak of ethnic violence against the Chinese in Jakarta and several other major cities is only the tip of the iceberg in terms of the deeplyrooted social envy and resentment towards the Chinese that were cultivated by the New Order's politics of ethnicity. ${ }^{6}$ The New Order used the Chinese as a cash cow to enrich a few powerful individuals in ruling positions, rather than as a potential force for economic development that could have helped to improve the nation's prosperity as a whole. ${ }^{7}$

The two novels discussed in this chapter, Perempuan Kembang Jepun (The women of Kembang Jepun, 2006) by Lan Fang and Dimsum terakhir (The last dimsum, 2006) by Clara $\mathrm{Ng}$, both of whom are of Chinese descent, can be read as direct responses to discriminatory practices against the Chinese in Indonesia. Lan Fang's novel focuses on a Japanese female geisha who went to the Dutch East Indies at the height of the Pacific War to disguise herself as a "comfort woman" for a Japanese army general, but the novel is as much about the Chinese as it is about this particular character, because she decides to assume a false identity as Chinese. A good part of the novel tells the struggle of this Japanese character to cope with her split ethnic identity, and through her eyes the readers come to understand how the Chinese experienced segregation and discrimination even during the Japanese occupation, prior to the birth of an independent republic. Clara Ng's work looks into the life stories of four girls who were born as quadruplets in a Chinese-Indonesian family that still upholds its ancestral traditions, and how each of these characters deals with her personal problems as well as her Chineseness in a society that has yet to accept them fully as integrated members. In both works, the readers are exposed to the complex intersections between gender, sexuality, and ethnicity, and the conflicts resulting from them. Both authors approach their characters as individuals who seek to establish their sense of self and agency amidst the various forces that try to subjugate them, rather than as characters that represent a certain collective identity. The narrative style in both novels allows the reader to have ample access to the inner struggle of each of the characters and witness how internal contradictions and dilemmas are dealt with.

\section{PEREMPUAN KEMBANG JEPUN: AMBIgUOUS CITIZENS}

Perempuan Kembang Jepun tells the life stories of its two female protagonists, Lestari (also known as Kaguya) and Matsumi (Tjoa Kim Hwa) by continually shifting between the past and the present, thus gradually revealing the

\footnotetext{
$5 \quad$ See Lim and Gosling (1997: 297-300) "Strengths and weaknesses of minority status for Southeast Asian Chinese".

6 See Nadj (2002: 102) "Problematika segregasi sosial".

7 See Anwar (2002: 144-145) "Kekuasaan dan dilema Etnis Tionghoa".
} 
characters' past traumas which influence the way in which they cope with reality today. Lestari is the lost daughter of Matsumi, a Japanese geisha shipped to Surabaya during World War II to entertain a Japanese army general. However, since geishas exist only in Japan, Matsumi had to disguise herself as a Chinese by the name of Tjoa Kim Hwa, working as a "comfort woman" in a brothel located in the Kembang Jepun district. Matsumi has an affair with a Javanese man, Sujono, and later lives with him and has a child. Due to his possessiveness, as well as the defeat of Japan in 1945, she abandons her daughter, Kaguya, and returns to Japan alone. Sujono raises this daughter with his Javanese wife and family and names her Lestari. She is endlessly tortured by Sujono's wife, Sulis, and raped by Joko, her stepbrother, when she has just entered puberty. Many years later, the grown-up Lestari runs an orphanage and adopts a young girl, Maya. Maya befriends a young Japanese photographer, Higashi, when he visits Kembang Jepun to take some photos. They fall in love, and Higashi visits Surabaya again with his mother to propose to Maya. The encounter of the two single mothers turns out to be fortuitous, because Higashi's mother is none other than Matsumi. Like Maya, Higashi was also adopted. Matsumi has fostered him since the age of five when she returned to Japan at the end of the war. Guilt, anger, and happiness blend as they both struggle to come to terms with everything that has happened.

Lestari is sixty years old and Matsumi is in her eighties. They are not only daughter and mother but also each other's in-laws. Perempuan Kembang Jepun is a compelling novel in the way it presents the muddling of identities and how the characters struggle with adversities, trauma, and contradictions in order to arrive at reconciliation. The most prominent male character is Sujono, a man without a permanent job who in 1945 is deluded by his pretentious illusion of becoming a revolutionary hero who will liberate his nation from foreign oppression. While Sujono significantly helps to shape the lives of both Matsumi and Lestari, in the end the two women have to find their own ways towards a mother-daughter reunion that allows them to make peace with their dark past. Through the flashback technique, the novel takes the characters back to the past to encounter and conquer their demons so that they may move forward for the sake of their children's happiness.

Matsumi arrives in Surabaya in 1942 along with the Chinese immigrants who fled their country because of the Japanese invasion. Her adopted Chinese name, Tjoa Kim Hwa, is given by her Japanese contact in Jakarta who helps to arrange her travel to East Java. Kim Hwa means "golden flower", while Tjoa could mean "snake". In this context, we can interpret "snake" as referring to the ability to shake off one's skin and develop a new one, whereas "golden flower" is a tribute to Matsumi's beauty, for she is the most beautiful comfort woman in the whole of Kembang Jepun. Kembang Jepun is a Malay phrase, which means "Japanese Flower", again a reference to the beautiful geisha who was said to have once lived there. Although present-day Kembang Jepun is in reality an important trading area in Surabaya, according to the novel in the past it was mostly inhabited by Chinese immigrants, and famous for its 
brothels. Matsumi is forced to hide her Japanese identity, because the presence of a Japanese geisha in Java would be scandalous and bring disgrace to Japan, which saw itself as the leader of Asia during the war. ${ }^{8}$ Matsumi upholds the geisha ethics until she meets Sujono. A geisha's most sacred duty is to serve her client, to entertain him, and to provide him with the utmost satisfaction, but she should not fall in love with any customer.

Her conflict begins when she lands at Surabaya harbour. She despises her assumed Chinese identity, as she has fixed biases and prejudices against the Chinese. In her view, they are "dirty and messy" (kumuh dan lusuh), and "their mouths and bodies stink" (tubuh dan mulut mereka berbau tidak sedap). She particularly loathes that she has to disguise herself as a Chinese woman, because "their feet are tightly bound with cloth until they become so small" (kaki mereka dibebat kain sehingga menjadi kecil sekali) so that "they cannot walk quickly, let alone run fast" (mereka tidak bisa berjalan lincah apalagi berlari cepat), unlike Japanese women who are able to move with agility when they wear kimonos and wooden sandals. Moreover, Chinese women "like to shout with a deafening and rude voice" (suka berteriak-teriak dengan suara nyaring dan kasar). ${ }^{9}$ Her geisha friend's words remain fixed in her head, that once Japanese she will always be Japanese despite her newly given identity. ${ }^{10}$ Nevertheless, Matsumi cannot help being shocked to see the terrible conditions of the comfort women who live in the same brothel but are forced to serve many soldiers every day, unlike her, who only serves the highest bidders. This is the first time she develops a sense of solidarity with the other women who are not Japanese, and is able to say to herself, "At least I'm also a woman. I'm also a woman who has to serve men for their ultimate satisfaction. But I don't have to merely open my legs to be penetrated by tens of soldiers every day". ${ }^{11}$ Furthermore, she ponders:

My woman's heart often cried out when I heard stories about those comfort women at the brothel house. Even though they're Javanese, Chinese and Korean, they're also women. Just like me. What is worse, they had to do their job against their will and under threats. It would be shameful and inappropriate for me to take pride in becoming the primadonna of the most expensive nightclub in Kembang Jepun. ${ }^{12}$

\footnotetext{
$8 \quad$ Lan Fang 2006: 94.
}

$9 \quad$ Lan Fang 2006: 93.

10 Yuriko, Matsumi's mentor in the geisha house in Tokyo, instilled in Matsumi's mind the need to preserve her nationalism and determination to eventually go back to Japan regardless where she is because, in Yuriko's words, "Japan is life" (Jepang adalah hidup), and "no matter how dark the sky is, Japanese will seek the sun, because the sun is life" (segelap apapun langit, orang Jepang tetap akan mencari matahari, karena matahari adalah hidup) (Lan Fang 2006: 106).

${ }_{11}$ Setidaknya aku juga perempuan. Aku juga perempuan yang melayani laki-laki untuk mencapai kepuasan tertinggi. Tetapi aku tidak hanya sekadar mengangkang untuk dimasuki puluhan laki-laki dalam sehari (Lan Fang 2006: 115).

12 Hati perempuanku kerap menangis bila mendengar cerita tentang para jugun ianfu di kurabu. Biarpun mereka orang Jawa, Cina dan Korea, mereka juga perempuan. Sama seperti aku. Apalagi mereka menjalani tugas itu karena terpaksa dan di bawah ancaman. Sungguh memalukan dan 
It is interesting to note that Matsumi specifically uses the phrase "my woman's heart" (hati perempuanku), which underlines her sense of solidarity and sisterhood with the non-Japanese comfort women who have to bear the worst treatment. This critical reflection emerges despite the fact that she only "hears stories" about those women and never sees their real conditions with her own eyes, as she is isolated from the others and placed in the best brothel in the area. What happens at this point is contrary to her initial attitude towards the Chinese comfort women. Matsumi ascribes her fortunate situation to the fact that she is Japanese, and not a Javanese, Chinese or Korean, even though at that time she has taken on the identity of Tjoa Kim Hwa. Her sense of Japaneseness is further reinforced by Hanada, the owner of the nightclub where she lives, who tells her that the Japanese general does not want a comfort woman (jugun ianfu). He wants a geisha instead, but nobody is allowed to find out that Matsumi is Japanese. As Matsumi utters, "Now I'm Tjoa Kim Hwa ... I'm a Chinese woman" (Sekarang aku Tjoa Kim Hwa ... Aku perempuan Cina), she embraces her new identity with mixed feelings but accepts it as a fact which she does not deny or reject. ${ }^{13}$

However, she also knows that Chineseness is an identity that she is expected to perform rather than adopt. The war, her patrons, and her dedication to her profession as a geisha demand that she be a Chinese comfort woman in public while remaining a geisha in private. Thus, Matsumi is displaced on two accounts: she is a Japanese disguised as Chinese, and she is a geisha displaced to an island far away from her homeland because of the war. As the plot unravels, Japan is on the verge of losing the war, and all the Japanese rush back to Japan in fear of retaliation from the local people. For a while Matsumi is safe as a Chinese, but she fears that sooner or later people will find out who Tjoa Kim Hwa in fact is. With the help of some kind-hearted Chinese she manages to board a ship to Japan, leaving Kaguya behind with a Chinese couple. Sujono eventually finds Kaguya in the temple based on the information given by some people who happen to see her there. Matsumi never stops blaming Sujono's possessive and abusive behavior for her having to leave Kaguya on Java. Aboard the ship, along with terrified refugees, Matsumi comes to the realization that she is indeed not different from the Chinese immigrants whom she saw at the port a few years before. She no longer feels that she is performing a Chinese identity, but that she is one of them:

Now I' $m$ also on a ship, but in a different condition and situation. I don't see the tired looks of the Chinese who strive for a new living. But I am a Chinese with a hopeless face, tired and worn-down, with eyes searching for the sun $[\ldots] I^{\prime} m$ not different from those Chinese whom I once pitied. In fact, now I'm the one who needs to beg for their sympathy. Now I'm crouching in a corner of this ship with nothing to own except a drop of breath and life as thin as a piece of paper. ${ }^{14}$

tidak pantas kalau lantas aku berbangga diri menjadi primadona di kelab hiburan termahal di Kembang Jepun (Lan Fang 2006: 135).

13 Lan Fang 2006: 135.

14 Sekarang aku juga berada di dalam kapal, tapi dalam kondisi dan situasi yang berbeda. Aku 
This is not a case of identity swap, but rather a poignant realization that comes out at the time of crisis, and it allows Matsumi to experience directly what the Chinese refugees had to endure several years before when they landed in Surabaya. Their new sense of being "in the same boat" with the Chinese goes beyond not only ethnic boundaries but also gender demarcations: men and women, Chinese and Japanese, all were innocent victims of a terrible war that changed their lives and took everything away from them against their will. At this point, Matsumi and Tjoa Kim Hwa are no longer two distinct identities but become blurred. What began as the performing of a fake Chinese identity has turned into a mind-opening experience, as a sense of solidarity and empathy develops.

Lestari, on the other hand, has to follow a completely different trajectory as she struggles to continue living with a sense of abandonment, having to take care of her ailing father who could never let go of the Japanese woman he loved till the end of his life. The half Javanese-half Japanese character never considers herself Japanese. In fact, her Japanese side contributes to the misery that she has to endure during her childhood. Ever since Matsumi abandoned her, "mother" has become an alien word for her. After her subsequent reunion with Sujono, she blames her lost Japanese mother for her childhood hardships. Later in life she initially opposes Maya's relationship with Higashi because it reminds her of her own childhood trauma. ${ }^{15}$ Their marriage not only serves as a symbolic union between a man and a woman but also as a reconnection of the tie between Lestari and Matsumi. As the mother-and-daughter relationship is eventually restored, Lestari re-embraces her Japaneseness by addressing Matsumi as Okasan ("mother" in Japanese). She accepts that Matsumi calls her Kaguya, her old Japanese name which she has been struggling hard to bury along with her dark past: "She calls me Kaguya! Again, that name sounds unfamiliar to my ears. But I can't help feeling that Okasan's quivering voice has brought fresh air to my soul that had been hollow for so many years". ${ }^{16}$ The reinstatement of the Japanese name that marks the reconciliation of mother and daughter also signifies the reestablishment of the mother-daughter generational hierarchy, and hence the performing of the role of daughter, with all of the etiquette that comes with that status.

Lestari's renaming as Kaguya, therefore, is not just a "reenactment" of "a set of meanings" that is already socially established and defines parenthood. It is, at the same time, a "re-experiencing" of that set of meanings by both the name-giver and the recipient. Butler uses these concepts to describe gender

tidak melihat wajah letih orang-orang Cina yang mencari penghidupan baru. Tetapi akulah orang Cina dengan raut putus asa, lelah dan lesu, dengan gurat mata yang mencari matahari [...] Aku tidak ada bedanya dengan orang-orang Cina yang dulu kukasihani. Justru sekarang akulah yang perlu dibelaskasihani oleh mereka. Saat ini aku meringkuk di pojok kapal tanpa memiliki apa pun kecuali seuap napas dan selembar nyawa setipis kertas (Lan Fang 2006: 120-121).

15 Lan Fang 2006: 21-23.

16 Ia memanggilku Kaguya! Lagi-lagi nama itu terasa asing di telingaku. Tetapi yang tak mampu kuhindari adalah ketika kurasakan getaran suara Okasan begitu menyegarkan jiwaku yang kosong berpuluh-puluh tahun (Lan Fang 2006: 238). 
as an "act" which requires the repetition of its performance in order to obtain legitimacy. Within the patriarchal system, the aim of such an act is to maintain "gender within its binary frame", which in turn serves to constitute the formation of a subordinate subject. ${ }^{17}$ In the case of Lestari's renaming, however, it is also a reenactment of a past action in which Matsumi-without Sujono by her side-named her baby girl Kaguya. Both in the primal event and its repetition, a masculine father-figure that should have marked the moment as an affirmation of the dominant "heterosexual matrix" is absent. But this does not mean that the consequence of the act is less repressive for Lestari than it would otherwise be if the act were carried out by a father-figure.

While Lestari decides to use this highly emotional event to free herself from the burden of the past, she is baffled by Matsumi's refusal to talk about Sujono or acknowledge the sacrifices he has made in bringing up Lestari: "I have revealed the darkest side of my life. I feel as if I' $m$ free from thousands of tons of heavy burden that has weighed down my life [...] Is Okasan just like me? Keeping all the wounds for herself. Choosing to forget them because she cannot forgive?"18 Lestari manages to come to terms with all of her internal conflicts, but Matsumi still drags her unhappy past behind her even after the reunion with her lost daughter. Lestari chooses to be quiet about it, trying to understand why Matsumi is behaving in such a way without asking questions. For Matsumi, Sujono is not part of the past that she has been trying to reenact in order to free herself from guilt. She regrets that she easily fell in love with Sujono, who was a frequent visitor of the brothel in Kembang Jepun, and ran away with him. For Lestari, the reunion with her mother is a bittersweet event. Freed from the ghosts of the past, she now has to learn to perform as an obedient daughter, after having lived as a woman who grew up independently without a mother's presence. She does so, if not for the sake of the newly restored relationship with Matsumi, at least for the sake of Maya's happiness. This may explain why at the end she admits that she experiences happiness, yet deep in her heart she also stores some feelings of disappointment: “To be honest, it's not hatred that I'm feeling, but a wave of disappointment that's welling up in my mind. But I don't know whom this disappointment is for ...". ${ }^{19}$ Lestari is a survivor, but Matsumi continues to be shackled by the past.

The novel provides the readers with a window into Sujono's life with his wife Sulis, and her struggle to save herself and her son from poverty. While she is portrayed as a villainous character, Sulis is actually a much fiercer fighter when it comes to defending her child than Matsumi was. As Sujono remains obsessed with how to free the country from foreign oppression, Sulis has to

17 See Butler 1990: 140.

18 Bagian paling hitam dalam lembaran hidupku sudah kubuka. Aku seakan-akan lepas dari ribuan ton beban yang selama ini menggelayuti batinku [...] Apakah Okasan juga seperti aku? Menyimpan luka itu sendiri. Memilih melupakan luka itu karena tidak bisa memaafkannya? (Lan Fang 2006: 257, 261).

19 Bila ingin jujur, bukan rasa benci yang kurasakan, melainkan tumpukan kekecewaan yang menggunung di batinku. Tetapi aku tidak tahu kekecewaan itu untuk siapa... (Lan Fang 2006: 277). 
sell traditional herbal medicines from one kampung (city district) to another to survive. For her, the most urgent issue is how to feed her son. Scarcity and poverty are far more concrete problems than fighting for the nation's independence. ${ }^{20}$ Sulis does not care for her own safety, but sticks to defending Joko to the end, even when it means losing Sujono. Her indifference to the Revolution and independence is founded on a very sound basis: a maternal instinct to protect her son in time of danger. Such a motherly predisposition was absent in Matsumi. Her loyalty to Japan prevails over her love for Kaguya, and she blames Sujono for her failure to choose her daughter over her homeland. The mother-daughter reconciliation does not entirely heal the scars of the past, although it reconnects the two characters.

According to Butler's theory of performativity, "the body becomes its gender through a series of acts which are renewed, revised, and consolidated through time", ${ }^{21}$ so gender performativity is effective "only to the extent that it is performed". ${ }^{22}$ Elsewhere, Butler discusses sex also as performative, by arguing that sex is not "a simple fact or static condition of a body, but a process whereby regulatory norms materialize 'sex' and achieve this materialization through a forcible reiteration of those norms". This reiteration is essential because it indicates that materialization is "never quite complete", as "bodies never quite comply with the norms by which their materialization is impelled". ${ }^{23}$ In this novel, each female character has to deal with an aspect of her gender but their problems are not exclusively related to sex: Matsumi is a geisha who disguises herself as a comfort woman, Lestari is an "unwanted" daughter who experiences a sexual assault committed by her step-brother, and Sulis is committed to her duty as a mother but rebels against the pressure to be a submissive wife. Butler's theory contributes to our understanding of the characters, not because of their sex and/or gender, but rather because of the attention it draws to the elements of coercion and subversion involved in performativity. The characters accept the dominant social norms, but in the process they "rearticulate" some aspects of those norms and, as Butler suggests, this opens up a possibility of subversion. ${ }^{24}$

Matsumi does not like disguising herself as a Chinese comfort woman, but her code of honor as a geisha compels her to carry out her duty without protest. What saves Matsumi from the tragic fate that the other comfort women meet is not the gender/sexuality she performs but her double identity. During the war she was safe because of her privileged status as General Kobayashi's mistress, and after the war she was safe because of her successful performance of being Chinese. Had they known that she was Japanese, nobody would have

$20 \quad$ Lan Fang 2006: 74.

$21 \quad$ Butler 1988: 523.

22 Butler 1988: 527.

23 Butler 1993: 236.

24 In Butler's view, the performativity of norms and laws always carries the possibility of turning the norms against themselves. Thus, the reiteration of the regulatory practice reinforces the norms, yet at the same time it can also bring about re-examination of the norms (Butler 1993: 236). 
been able to guarantee her safety, as anti-Japanese sentiments were strong. Further, she is able to develop a sense of gender solidarity with the other women, which goes beyond racial or ethnic boundaries. It helps her develop a critical awareness of the Japanese soldiers' brutal treatment of those women. That Matsumi is eventually re-interpellated by the call of Japanese nationalism demonstrates that, even if there are subversive moments and possibilities in performing an alternative identity, in the end the hegemonic force is reinstated and strengthened. Matsumi's actions are frequently dictated by circumstances that thrust themselves on her, as she admits: "[...] I always let Life control my life. I never protest or say no" ${ }^{25}$ The only time she feels that she makes her own decision about her life is when she decides to leave the brothel and live with Sujono, only to find out later that her dreams are shattered by his possessive behavior.

Lestari enjoys adult life as an unmarried woman despite the absence of a mother figure. She has more affection for Sujono than for Matsumi, and her love for him remains intact, in spite of the terrible stories she hears about him from Matsumi. Her ambiguous feelings towards Matsumi notwithstanding, Lestari agrees to readopt her Japanese name and reenact the role of daughter, which entails love and obedience towards her mother. She resists the urge to question Matsumi about her motives for abandoning her or to try to persuade her to forgive Sujono. She simply chooses to settle with a conclusion that "only the love between a mother and a child is the sweetest and most beautiful kind of love. Love of the deepest kind. Happiness" ${ }^{26}$ This may be the only sensible option for her if she wants Maya and Higashi to be happy, for any rift between Lestari and Matsumi may affect their happiness as well. Thus, any subversive potential in Lestari's performance as a daughter has to be suppressed so that order, peace, and happiness in the family may not be jeopardized.

Sulis is the only character who chooses to commit herself fervently to her performance as a mother. Her life focuses entirely on raising Joko, and Sujono only occupies a marginal space therein. She gradually loses her respect for him, and that lack of respect quickly turns into hate when Sujono brings Lestari home. Chandra Mohanty writes that 'women' should not be understood as a homogenous group with shared labels such as "powerless, exploited, sexually harassed" ${ }^{27}$ She criticizes the ways in which western feminist texts represent "Third-World women" as being dependent and apolitical, as well as "victims of race, sex, and class". ${ }^{28}$ Sulis refuses to see herself as a victim, she is not suffering from dependency, and she has a strongly articulated political standpoint. Moreover, gender equality is not the main issue for her, and mothering is not an evidence of oppression but a meaningful activity. Sulis is a manifestation of women as constituted by a "complex interaction" between

25 [...] aku selalu membiarkan Sang Hidup yang mengatur jalan hidupku. Aku tidak pernah membantah dan berkata tidak (Lan Fang 2006: 140).

26. Hanya cinta ibu dan anak yang paling manis dan indah. Cinta dari seluruh rasa terdalam. Bahagia (Lan Fang 2006: 279).

27 Mohanty (2003: 22-23) "Under Western eyes".

28 Mohanty 2003: 25. 
many different issues, including "class, culture [...] and other ideological institutions and frameworks", as Mohanty argues, and not a monolithic group that is solely constituted by its gender. ${ }^{29}$ To the end, Sulis remains unequivocal about mothering even if she has to lose Sujono, as she tries to rescue Joko from his wrath in the aftermath of Lestari's rape. Her performance of mothering, while conforming to social expectations, defies the conventional mothering norms which require the constant and dominant presence of a husband as a breadwinner and head of the family. It further subverts the dominant norms by revaluing mothering not as an act of necessity but as an expression of unconditional love.

\section{DIMSUM TERAKHIR: NEGOTIATING CHINESENESS}

Dimsum terakhir revolves around the lives of fictional quadruplets with contrasting personalities and traits, born into a Chinese-Indonesian family that struggles to preserve its ancestral traditions. Each of the four female characters, Siska, Indah, Rosi, and Novera, has her own personal problems and secrets to deal with. Siska lives and works in Singapore as a CEO of a flourishing company, Indah works in Jakarta as a journalist and novelist, Rosi runs a rose plantation in Bogor, and Novera is a school teacher in Yogyakarta. They are reunited in the old family house in Jakarta because Nung, their father, is terminally ill. The reunion turns out to be eventful, as their secrets and individual conflicts are gradually revealed. The plot oscillates between the present-day predicaments that the characters are facing and reminiscences of past events which significantly influenced the paths taken by each of them, and how they struggle with their identity problems. Amidst the frequent switches of time and points of view, the reader finds portions of the story narrated by the ghost of their late mother, Anas, who pays a visit to the house during the celebration of the lunar New Year. In addition to the quadruplets and their parents, some secondary characters are introduced: Dharma, Rosi's same-sex partner; Antonius, a Catholic priest who impregnated Indah but refuses to bear paternal responsibility; and Rafy, whom Novera asks to pretend to be her boyfriend in order to make Nung happy during his last weeks. The catalyst of the conflict is Nung's final request that his four daughters be married before he leaves this world.

Siska, the oldest quadruplet, is an outgoing and sexually active single woman with solid self-confidence. She successfully manages her own company and travels frequently to meet with clients. When Indah calls her to inform her about their father's condition, Siska is in the midst of making love with a male client in a hotel room in Hong Kong. This one-time exception to her rule not to get involved with clients will later cause her trouble, as she is set up and accused of sexual harassment. Being a successful, independent woman, Siska does not believe in marriage. Her dismissive attitude towards it is partly due to her past, unpleasant experience of being jilted by her fiancé who, 
unbeknownst to her, had an affair with another woman. Siska swore to never again attach herself to just one man: "She doesn't need a boyfriend, let alone a husband [...]. She doesn't need to be a loyal wife, cook, and raise a bunch of cute children. She doesn't need the title 'wife' or 'missus' or 'mommy'. She is Siska Yuanita, CEO with only one title: freedom". ${ }^{30}$ She strongly objects to her father's wish to see all his daughters married before he dies, whereas all her sisters scramble in panic to find ways to avoid having to fulfill the wish. In her own words, Siska asserts with confidence and determination, "I don't want to set a target for marriage because marriage is not a life's target [...] nobody - including Daddy - can set a target for my personal life". ${ }^{31}$

Underneath her seemingly complete confidence, however, Siska is struggling with her Chinese-Indonesian identity. She suspects that her Hong Kong clients like to gossip behind her back about the fact that she looks Chinese but cannot speak the language; among overseas Chinese it is common knowledge that Chinese-Indonesians very likely do not speak Chinese. Yet at times she can fiercely defend her Chinese identity, especially when it is under attack. She balks at the idea of Novera receiving Catholic baptism, and thinks that her sister has brought shame and disgrace to the Chinese by converting to Christianity. ${ }^{32}$ Although she is aware of her marginalized position in Indonesia as a Chinese, she refuses to condemn the government, which she thinks is mainly responsible for the prolonged discriminatory practices against minorities. She prefers to work hard and not blame anybody for her situation, and realizes that poor descendants of Chinese in Indonesia live in even worse conditions than recent immigrants, as they had to endure both poverty and discrimination. ${ }^{33}$

In contrast to Siska, Indah has low self-esteem, which is partly caused and reflected by a speech impediment that makes her stutter, especially when she is under pressure. On the other hand, she is described as a perfectionist, which can be interpreted as a means to compensate for her feeling of inadequacy. She has successfully published her first novel but is suffering from a crisis as she is unable to start a second work of fiction while her fans urge her to produce a new book. As the second oldest of the quadruplets, Indah never stops wondering how she could be related to her sisters, Rosi and Novera, whom she thinks are totally incompatible with her in terms of personality and preferences. In addition, she often loses her patience when she has to deal

30 Dia tidak butuh pacar, apalagi suami [...]. Dia juga tidak perlu menjadi istri yang setia, memasak dan membesarkan sepasukan anak yang lucu-lucu. Dia tidak perlu gelar "istri" atau "nyonya" atau "mami". Dia Siska Yuanita, direktur eksekutif yang mempunyai satu titel: freedom (Clara Ng 2006: 89-90).

31 Aku tidak mau memasang target soal pernikahan karena menikah bukanlah target hidup [...] siapapun - termasuk Papa - tidak dapat menentukan target itu terhadap hidup pribadiku (Clara $\mathrm{Ng}$ 2006: 149).

32 When Novera discloses to the family that she is converting to Christianity, Siska is amongst those who strongly oppose the idea. She says, "Jangan bikin malu orang Cina. Tidak usah pakai acara baptis-baptisan" (Don't disgrace the Chinese. Forget baptism) (Clara Ng 2006: 72).

33 See Clara Ng 2006: 230-232. 
with Siska's eccentricity, and has considered Siska her natural enemy since birth. Carrying the main burden of taking care of her father and the family house on her shoulders, she feels that it is not fair. Therefore, disregarding her sisters' objections, Indah insists that they all stay in Jakarta during Nung's treatment. Aside from her writer's block and Nung's poor health, Indah has to come to terms with the fact that Antonius, her secret lover, cannot make up his mind about whether he should leave the Catholic priesthood and marry her. He believes that he is already married to the Church, and thinks that Nung will not approve of their relationship even if he leaves the priesthood, because he is Javanese.

Although she looks weak, Indah actually has a cunning mind. She manages to make her sisters stay in Jakarta despite their grudges, she lures Antonius into a romantic relationship with her, and in the process of writing her first novel she was able to exploit her Chineseness to make it a best-seller. That book concerned the Chinese in Indonesia and their social-political struggles, based on her own diary, and she has to admit that the novel sold well because no other Indonesian writer had explored the lives of overseas Chinese before. ${ }^{34}$ Regardless of her weaknesses, however, Indah - in Novera's eyes - serves as the glue that binds the family together and preserves its traditions. Indah's development as a character is visible in the ways in which she deals with each of her personal problems. When she finds out that she is pregnant, she decides not to abort the fetus: "Her decision to complete her pregnancy is not an easy one. Frankly speaking, at first she didn't really want to keep the baby [...]. The closer the delivery time comes, the more complete her suffering and happiness are. Mixed into one. Muddled". ${ }^{35}$ She is able to stand up to Siska, who tries to persuade her to have an abortion. Indah finds the idea repulsive: “... abortion? That word feels like a cold wind that causes her heart to freeze. To abort means to murder. Realizing the similarity, Indah's heart bleeds. It hurts" ${ }^{36}$ During Nung's funeral, when Antonius shows up and tries to talk with her, Indah is able to overcome her feelings for him and indicates that she will do just fine bringing up the baby alone without him. Even though Indah's pro-life view may be considered "conservative", she is transformed into an independent woman with self-confidence. She no longer aims at perfection, which was a driving force behind her success as a novelist but also an impediment to her efforts to gain confidence and find out what she really wants as a woman.

Rosi, the third sister, has the most complex gender identity problems, compared to the others. She likes to dress like a man, has her hair cut short, and at first she is living as a lesbian. She keeps her girlfriend, Dharma, secret from

34 Clara Ng 2006: 207-208.

35 Keputusannya mempertahankan kehamilan memang bukan keputusan mudah. Terus terang, mulanya dia memang tidak sungguh-sungguh menginginkan bayi ini [...]. Semakin tua usia kehamilannya bertambah, semakin lengkap penderitaan dan kebahagiaan Indah. Bercampur rata. Teradukaduk (Clara Ng 2006: 316).

36 Menggugurkan? Kata itu bagai angin dingin yang langsung membekukan hati Indah seketika. Menggugurkan berarti membunuh. Menyadari sinonim kata tersebut, hati Indah berdarah. Sakit rasanya (Clara Ng 2006: 270). 
her family, as she does not want them to find out about her sexual orientation. She first became aware of her difference when she was twelve years old, and began to hate her female body. She did not want to be a woman. She was happy that her first period did not come until late, at the age of twenty, as she feels that she is trapped in the wrong corporeality, she is actually a man in a woman's body. This forces her to live a split life: to herself she is Roni, not Rosi, but only Dharma knows this secret and calls her by her male name. Rosi's problem becomes even more complicated, as being Chinese she also has to come to terms with discrimination against ethnic minorities, and her sexual orientation makes the situation worse for her. To escape from the contradictions and injustice she faces, Rosi feigns indifference: she does what she wants to do, and disregards anybody else. In short, she wants to break all the rules because, in her opinion, rules are made by those who consider themselves "normal". ${ }^{37}$ However, she realizes that her primary enemy is herself: "She is on the verge of her deepest and steepest self, which remains hidden and messed up. Her split self. The self she's been trying to get rid of for years. The self that manages to survive, living inside her body". ${ }^{38}$ Roni is introduced for the first time in the narrative when the plot switches to a flashback, when Rosi was eighteen:

Roni is masculine and handsome, even though his personality is a reflection of Rosi's. Roni is Rosi, in the 'truest' manifestation. Roni has been present inside Rosi since the girl reached adolescence, when the awareness of her existence began to surface. At first, Rosi prevented Roni from coming out, leaving him imprisoned quietly deep down under her subconscious. When finally Roni dared to show himself, Rosi could hardly do anything to stop him..$^{39}$

Although Rosi tries hard to hide her transgender identity, her sisters have some inkling of her split selfhood. She almost gives away her sexual preference for women when she accidentally says in front of her sisters that making love with men is disgusting. ${ }^{40}$ Indah sometimes wonders why Rosi has her hair cut very short, for that makes her look both beautiful and handsome in her eyes. ${ }^{41}$ Siska has been suspicious that Rosi is hiding a secret about her sexuality, since she caught her wrapping a piece of cloth around her body to flatten her breasts. On another occasion, Siska rescued Rosi when she tried to commit suicide by

37 Clara Ng 2006: 45.

38 Dirinya yang berada di dalam jurang sanubari terdalam, sembunyi dan mengacak-acak jiwanya. Dirinya yang terbelah. Dirinya yang berusaha dia usir selama tahun-tahun belakangan ini. Dirinya juga yang berhasil bertahan, hidup di dalamnya (Clara Ng 2006: 41).

39 Sosok Roni gagah dan tampan, walaupun pribadinya adalah pantulan cermin Rosi. Roni adalah Rosi, dalam bentuk yang "sebenar-benarnya". Roni memang telah hadir dalam diri Rosi semenjak gadis itu mencapai usia puber, ketika eksistensi diri mulai muncul ke permukaan. Mulanya Rosi mencegah Roni muncul ke permukaan. Membiarkan dia terpenjara diam-diam di alam bawah sanubari. Ketika akhirnya Roni benar-benar berani menampakkan diri, Rosi nyaris tidak dapat berbuat apa-apa (Clara Ng 2006: 121).

40 Clara Ng 2006: 215

41 Clara Ng 2006: 80. 
taking an overdose of pills. Rosi finally reveals to Siska that she believes she is actually a man who likes women, although at first she thought she was a lesbian: "admitting that she's a lesbian is easier. Nowadays, lesbians and gays are becoming more acceptable in society [...]. But women who become men? They're hiding, not easy to identify, and no matter what, there will still be many who cannot understand them" ${ }^{42}$ Rosi feels that she is one hundred per cent male, a man who desires women, ${ }^{43}$ and that she is 'normal' because she is not a lesbian. Throughout her period in the closet, she takes advantage of the fact that society more readily accepts women who dress and act like men, rather than the other way around. It helps her avoid society's condemnation. It would have been different if she were physically a man but wearing women's clothes and cosmetics. ${ }^{4}$ Her relationship with Dharma was at a low point when Dharma criticized her indecision and accused her of being subservient to patriarchy. Rosi was offended, and her Chineseness came up in defense of the Confucian value of filial piety, which applies to both sons and daughters, that her family has upheld for a long time: "This isn't patriarchy. This is Chinese culture. Chinese kids have an obligation to respect their parents. [...] It's my obligation, taught by Mommy. I must not neglect Daddy. It's bad feng shui. Bad karma. [...] Don't insult the strength of Chinese culture. You've insulted an extraordinary people". ${ }^{45}$ Thus, for Rosi, her ethnic identity is by no means less important than her sexuality, and she is willing to fight for it even if it puts her relationship with Dharma in jeopardy.

Nung discovers that Rosi thinks she is actually a man trapped in the female body, as he has a chance to talk with Dharma when Rosi is not present. Although Nung admits that it is a shocking discovery, he gives his blessing to their relationship: "I just want to be frank, that I don't have any clue about this stuff. In my era, we never heard of women wanting to be men or women falling in love with other women. As a parent, at first I was confused. What should I do? But no matter what, Rosi is my daughter whom I love very much" ${ }^{46}$ When Nung dies, the quadruplets agree that Rosi should be the flag-bearer leading the funeral procession, a tradition carried out by the eldest son at a funeral ceremony among Chinese-Indonesians. This signifies their acceptance of Roni as an inseparable part of the family and as fulfilling a male role:

42 Mengaku lesbian jauh lebih muda. Pada zaman sekarang, sudah semakin banyak masyarakat yang dapat mengerti dan menerima lesbian dan gay [...]. Tapi perempuan yang menjadi lelaki? Mereka lebih tersembunyi, sulit dikenali, dan sampai kapan pun, masih banyak orang tidak dapat mengerti (Clara Ng 2006: 224).

43 Clara Ng 2006: 182.

44 Clara Ng 2006: 182-83.

45 Ini bukan budaya patriarki. Ini budaya Cina. Anak-anak keturunan Cina diwajibkan menghormati ibu-bapaknya. [...] Itu kewajibanku, yang diajarkan oleh mamaku. Aku tidak boleh menyianyiakan papaku. Feng shui jelek. Karma buruk. [...] Jangan menghina kekuatan budaya Cina. Kamu menyinggung bangsa yang luar biasa ini (Clara Ng 2006: 192-193).

${ }_{46}$ Oom cuma mau terus terang, sebenarnya Oom nggak ngerti yang beginian. Di zaman Oom, nggak pernah kedengaran perempuan yang mau jadi lelaki atau perempuan yang naksir sama perempuan lainnya. Sebagai orangtua, Oom bingung mulanya. Mau diapain? Tapi biar bagaimana, Rosi anak perempuan Oom yang Oom sayangi (Clara Ng 2006: 321). 
The smoke of the incense stick rises to the air. Its fragrance slips into her heart. The deafening noise of cymbals sounds like music to her ears. Strange songs in an alien language flow in perfection [...]. Roni is lying on the ground. This is an extraordinary event. It's an orchestration of the recognition of her sexuality regardless of what people might say. ${ }^{47}$

Novera, the youngest quadruplet, is by nature shy and reserved, but she can be very persistent. Like Indah, she suffers from an inferiority complex, and compared to the rest she is the least ambitious. When they were small, Novera was the one who often fell sick. Although they look physically alike, Novera has always thought that she does not share anything with her sisters and hates it when people compare them in order to find similarities. She is the only one in the family who converts to Catholicism, in spite of her mother's and sisters' opposition. Anas feared that once Novera became a Catholic, she would not want to touch incense sticks anymore, and might later force her to be a Catholic, too. Only Nung was sympathetic to Novera's conversion, because he believed that Catholicism would help her to be a woman with a modern mind. ${ }^{48}$ At one point in her life, Novera decides to be a nun. She is convinced that this is the most courageous decision she has ever made in her life, for she has always perceived herself as a person with a lack of bravery. It is noteworthy that even though Novera is converting to Catholicism, she is the only one who continues the family tradition of fasting during the Ce It and Cap Go celebrations after Anas' death. ${ }^{49}$ Novera's persistence is visible in her steadfast adherence to Catholicism, as well as her strong sense of attachment to tradition. She does not care that her sisters think that their family traditions belong to the Stone Age and are no longer relevant in the present time. ${ }^{50}$ However, when Nung announces his wish to see his daughters married before his death, Novera makes up a fictional relationship. This is where Rafy, a fellow teacher in Yogyakarta, comes into play, as he has to pretend to be Novera's boyfriend, with the expectation that upon learning about the relationship Nung will be able to die peacefully.

Like her sisters, Novera has a personal secret that is revealed to the readers nearly halfway of the story. She is unable to bear children, as she had a hysterectomy when doctors found a malignant tumor. Novera considers the womb the most valuable possession that women have: "If her womb is taken away, what else remains of her? Her sense of self and identity will be robbed in a degrading way. She is nobody without a womb. She'll stop being

47 Asap hio mengepul di udara. Wangi, masuk menyelinap di hatinya. Suara kerencengan berbunyi bagai lagu di telinga. Nyanyian aneh berbahasa asing mendayu sempurna [...]. Roni rebah, kepalanya serata tanah. Ini peristiwa istimewa. Ini orkestra tentang pengakuan atas seksualitasnya. Masa bodoh apa kata orang-orang (Clara Ng 2006: 348).

48 Clara Ng 2006: 71-74.

49 Ce It refers to the first day of the first month in the New Year in the lunar calendar, whereas Cap Go refers to the fifteenth day leading towards the Imlek celebration, the most important celebration amongst overseas Chinese in Indonesia.

$50 \quad$ Clara Ng 2006: 155-156. 
Novera" ${ }^{51}$ This sense of being an incomplete being is her main reason for turning to religion and wanting to become a nun. Religion gives her hope, a metaphorical new womb that offers her a new kind of future. She feels that if people know of her hysterectomy, she will become an object of pity as it will be almost impossible for her to find a husband. She fears becoming an old maid, and in order to fight that fear, she makes the decision to be a nun: "Old maid, is that how they call it? I don't want any pity. I really don't mind being unmarried. Why do women have to marry?" 52 Like Rosi, Novera once tried to kill herself by cutting her wrist, but Siska appeared in time to stop the bleeding and save her life. Novera discloses her plan to enter the convent to Rosi, when Rosi tells her that she is really Roni. Novera eventually comes to the point where she can survive without marriage and be an independent person, but her reason for coming to such a conclusion is based on frustration and disappointment rather than clear reasoning. She can never recover from her broken heart, because her former boyfriend left her after discovering that she cannot have children. What Novera does not realize is that Rafy is willing to come to Jakarta and pretend to be her boyfriend in front of her family, because he loves her as she is.

From the perspective of Butler's theory of gender performativity, these quadruplets find themselves in situations that are not of their own making: they are born Chinese and therefore marginalized by Indonesian society, and they are women who have to live up to their culture and society's expectations with regard to sexuality, femininity, marriage, and motherhood. They refuse to succumb to society's stigmatization of the Chinese as descendants of "immigrants", who are not considered patriotic enough as loyalty is assumed to be divided. They perform their Chineseness fiercely, complying with society's perception that the Chinese cling steadfastly to their ancestral traditions, and at the same time disproving the stereotype that the Chinese are not loyal and hard-working citizens of Indonesia. In addition, each of them has to deal with past traumas which provide them with the force to keep going, but at the same time prevent them from living without masks and pretense. Siska draws her confidence and independent spirit from her former boyfriend's betrayal. Indah looks indecisive, but she knows how to exploit her Chineseness to publish a novel and make herself a "celebrity" writer. Rosi has to perform as a woman and deny her sexuality and identity as Roni. Novera, the youngest, spends much of her life on the run, trying to escape from having to confront her ethnic identity problem and her sense of inadequacy. She finds that religion and teaching pre-school children provide her with a safe haven and an opportunity to continue living.

As a result, these characters perform multiple identities simultaneously: the identities assigned to them by their gender and ethnicity, as they deal with

51 Jika rahimnya diangkat, apa yang tersisa pada dirinya? Jati diri dan identitasnya dirampas dengan tidak hormat. Dia bukan siapa-siapa tanpa rahim. Dia bukan Novera (Clara Ng 2006: 160).

52 Perawan tua, begitu kan istilahnya? Aku nggak mau dikasihani. Aku sungguhnggak keberatan tidak menikah. Mengapa perempuan harus menikah? (Clara Ng 2006: 256). 
their struggle to be fully accepted as Indonesians; and their duty to preserve the family's tradition by honoring their father. In their efforts to carry out these complex and often conflicting demands, they have to sacrifice their personal desires and dreams. Finding and carving out a niche for self-fulfillment amidst all these constraints is an endeavor that each of the quadruplets undertakes. Underneath her cosmopolitan attitude, Siska feels the need to be in touch again with her roots: her family and her Chinese-Indonesian identity. Indah realizes that her obsession with producing another masterpiece and forcing Antonius into marriage might in the long run destroy her, so she decides to return to the role she can perform best: to be the "glue of the family" and guardian of tradition. Rosi finally manages to resolve her split gender identity by allowing Roni to gain his rightful existence as a male transgendered person, even though it means that she essentially falls back into the conventional gender binarism. Novera stops running and comes to terms with the fact that there is a man who truly loves her, so she may end up fulfilling Nung's wish, reiterating the heteronormative norms of marriage and family building. The characters follow circular trajectories that eventually lead them back to conventional norms, and although there are moments of rebellion they do not significantly shake the foundations of those norms. In the end, each one's personal quest reinforces to a large extent a conventional performance of their gender and ethnic identities, with Rosi/Roni switching sides. All is done for the sake of family unity. This is aptly illustrated by the description of the family house, which "really smells of the past. As if the house didn't move forward to the future. Time freezes in this house, it doesn't move even a second. [...] The house is a time machine to travel back to the past". ${ }^{53}$

A year after Nung's death, the quadruplets get together again in a family reunion at the old house to celebrate Imlek and have early-morning dimsum. Tradition is preserved and the house remains alive: Dharma, Rafy, and Indah's baby have become new members of the family, with Nung's and Anas' spirits watching contentedly from a corner of the house. This confirms Siska's conviction that the family and its traditions will survive: "I don't believe in the last dimsum. [...] Daddy and Mommy will always be present at our Imlek celebrations". ${ }^{54}$ This is what Nung and Anas have always wanted to see, and may be the reason why their ghosts linger in the house. For them, the house contains not only the history of their lives but also that of the lives of their ancestors, since their arrival in this land in the sixteenth century. From then on, the house has served as a center that holds everything together, as well as a point where Chineseness and Indonesianness blend. Nung had already given two names to his daughters: Chinese names that he personally picked, and Indonesian names which he and Anas entrusted their indigenous

53 Rumah ini benar-benar berbau masa lalu. Seakan-akan rumah ini tidak bergerak menuju ke masa depan. Waktu di rumah ini membeku, tidak maju sedetik pun. [...] Rumah ini adalah mesin waktu untuk kembali ke masa lalu (Clara Ng 2006: 156).

${ }_{54}$ Aku tidak percaya dimsum terakhir. [...] Papa dan Mama akan selalu hadir dalam perayaan Imlek kita (Clara Ng 2006: 339). 
housemaid to choose for the girls. Chinese friends and neighbours criticized them and protested that calling the girls by Indonesian names was an act of betrayal of their Chinese identity. ${ }^{55}$ But Nung remained firm in his belief that "names won't change them into somebody else. In their bodies runs Chinese blood. [...] An overseas Chinese won't stop being Chinese ... with or without a Chinese name" ${ }^{56}$ Although Nung's notion of Chineseness is obviously rife with essentialism, it makes sense in the context of their survival amidst the suppression of the Chinese during the New Order era. The government issued an edict that strongly urged Chinese-Indonesians to fully assimilate themselves into the Indonesian society by adopting Indonesian names and abandoning ancestral practices. ${ }^{57}$

Nung uses "strategic essentialism" 58 to cope with the dilemma of preserving tradition on the one hand and complying with the demands of an oppressive regime on the other. His daughters' public names no longer refer to their ethnic identity, but Chinese traditions continue to be practiced and celebrated in the family. Thus, naming becomes an instrumental part of performative politics, and they are adopted and adapted as a survival strategy, detached from their main role as signifiers of ethnic identity. In this respect, a name is like a mask that an actor puts on to act out a role that does not conform to his or her own real life persona. In the case of the quadruplets in Dimsum terakhir, however, the Indonesian names with which they are identified in their daily lives have a significant impact on the characters' attitudes and standpoints regarding their sense of citizenship and hybrid identity. They strongly feel that they are Indonesian, in spite of their experience of discrimination and prejudice. In this sense, the new names have a performative function of changing the faces behind the masks. Furthermore, their Indonesianness does not clash in any way with their sense of Chineseness, although it adds complexity to the intersections of such multiple hybrid identities.

That they cannot speak Chinese does not make it easier for them to celebrate their hybridity. In Chinese communities in Indonesia, not speaking Chinese is a sign of disrespect to the ancestors and makes one an "outsider" in

55 See Clara Ng 2006: 203-205.

$56 \quad$ Nama tidak akan mengubah mereka menjadi orang lain. Di dalam darah mereka mengalir darah Cina. [...] Seorang keturunan Cina tidak akan berhenti menjadi Cina ... dengan atau tanpa nama Cina (Clara Ng 2006: 206).

57 In December 1966, following the massacres of hundreds of thousands of suspected communists, including many Chinese-Indonesians accused of working for Red China as collaborators and spies, the government issued a regulation on name changing for ChineseIndonesians. This was followed by another decree a year later, which prohibited the practice of Chinese beliefs and rituals, as well as the use of the Chinese language. Imlek could only be celebrated within the family. In the year 2000, after the Reformasi, the decree was revoked by Abdurrahman Wahid's administration. See Lohanda, "Masalah Cina" (2002); Nadj, "Problematika segregasi sosial" (2002); Subiakto, "Ketika produk hukum melegalisasi praktek diskriminasi" (2002); Lie, “The Chinese problem" (1999a) and “On assimilation" (1999b).

58 The phrase is coined by Gayatri Chakravorty Spivak in The Post-Colonial critic (1990) to refer to the inevitability of essentialism in certain situations, but at the same time there is also awareness that it should always be a provisional measure taken to deal with the situations. 
the eyes of the ethnic community of origin as well as the indigenous majority. This dilemma is described by Ien Ang, who as an overseas Chinese who does not speak Chinese explores the "indeterminacy of Chineseness as a signifier of identity" ${ }^{59}$ For Ang, Chineseness is "a category whose meanings are not fixed or pregiven, but constantly renegotiated and rearticulated" ${ }^{60}$ Ang talks about Chinese communities in diaspora, who share collective memories of the "homeland" and tend to develop a "diasporic identification" with it. However, such diasporic experiences put a limit to how far "Chineseness" can be transmitted and negotiated. The quadruplets in Dimsum terakhir do not have any collective memory of the "homeland", as they were born and grew up in Indonesia. Any notion of "home" in their minds relates to Indonesia. Their problem is not only how to be at home and accepted in Indonesia, but also the sense of being "impure" in the eyes of other Chinese for not being able to speak the language. They are, as Ang puts it elsewhere, "too Chinese" and simultaneously "not Chinese enough" ${ }^{61}$ This explains why a strategically essentialist position has to be taken in tandem with a negotiated compromise, as reflected in Nung's decision to give his daughters two names, refusing either one as exclusive.

\section{CONCLUSION}

Most of the female characters in Perempuan Kembang Jepun and Dimsum terakhir opt for reconciliation, to preserve their family's unity at the expense of their personal freedom, and sometimes even their individuality. In the first novel, only Matsumi remains unchanged by time and events, as she firmly believes to the end that her Japaneseness is important above everything, and therefore gives up her child and returns to Japan. Lestari is willing to re-adopt the role of a devoted daughter to restore her relationship with Matsumi and ensure that Maya may live happily with Higashi. Sulis dedicates her whole life to mothering and disregards the nationalist call to join the cause of independence. In the second novel, the quadruplets have personal identity struggles to deal with, but at the critical point when the family unity is threatened they are ready to set aside their individual ambitions and aspirations in order to preserve their family's tradition.

The characters in these novels may look conservative and submissive vis-à-vis familial duties, which represent traditional values that are sometimes considered oppressive to women's aspirations for equality. However, such a conclusion may be hasty, and misguided by dominant, liberal feminist discourses from the West. As Mohanty points out, they tend to dismiss everything that impedes women's struggle for gender equality as "oppressive", whereas for many women in the so-called "Third-World" gender equality may not be a priority in their lives. ${ }^{62}$ The family, motherhood,

\footnotetext{
59 See Ang (2001: 21-51) On not speaking Chinese.

60 Ang 2001: 25.

61 Ang 2001: 32

62 See Mohanty 2003.
} 
and the household economy may be more urgent issues for them to face in everyday reality than fighting for personal rights and freedom, or for the nation's freedom from foreign oppression for that matter. These women refuse to be lured by either nationalist glory, as shown by Sulis in Perempuan Kembang Jepun, or by the promise of "personal freedom" that the quadruplets abandon in Dimsum terakhir. This does not necessarily mean that they do not value personal freedom and individuality, but these qualities are not considered more valuable or important than family tradition and values. The characters in these two novels find in their own ways that identity may be a crucial issue, yet it is an issue that cannot be dealt with separately from other issues surrounding their everyday lives. They may be ready to adopt an essentialist standpoint with regard to one problem in order to confront another problem, as the quadruplets do in trying to make space for their Chineseness amidst the conflicting demands of preserving family unity and affirming their loyalty to Indonesia.

In the context of post-1998 Indonesia, these two novels contribute to a critical reexamination of the ethnic politics sanctioned by the New Order, which tended to use the Chinese as a cash cow when the economy flourished and a scapegoat when the economy was in crisis. While the May 1998 mass rape of Chinese women has resulted in a radical overhaul of government policies that disadvantaged the Chinese community in Indonesia, discriminatory practices against them by both public officials and fellow citizens still take place from time to time. The Chinese have come out from hiding, and more voices from within the community have been heard that demand an end to the treatment of the Chinese as second-class citizens. Since 2000, the government allows Imlek to be celebrated in public, along with the performance of lion dances, which used to be prohibited during the New Order era. Chinese political participation has increased ever since, as is evident in the establishment of several Chinese social organizations and political parties. The controversial law which ruled that the Chinese had to carry a special document as proof of their citizenship has already been revoked. In addition, Confucianism has been officially recognized by the state as one of the major religions. ${ }^{63}$

However, what is more important than tokens of official recognition of Chineseness as part of Indonesia's multiculturality is the sense of being a permanent part of Indonesia, and not just a supplement to it. An appreciation of their cultural tradition can be seen as enriching the repertoire of Indonesian cultural heterogeneity, rather than a dangerous, imported alien culture. In Dimsum terakhir, this sense of being "at home" does not lead to an overtly

63 Before the Reformasi, five religions were recognized by the state: Islam, Christianity (=Protestantism), Catholicism, Hinduism, and Buddhism. Confucianism has become the last system of belief to be accommodated by state law. The Indonesian Constitution rules that every Indonesian citizen has to adhere to one of the religions that are recognized by the state. However, there are actually hundreds of other systems of belief that exist in Indonesia that do not fall into one of the major categories. The state considers them as 'sects' (aliran kepercayaan), but allows them to be practiced since these so-called 'sects' have been around for centuries in the archipelago long before modern and organized religions came in. 
nationalistic attitude. Rather, it finds its manifestation in a family reunion that brings the four sisters together every year when they celebrate Imlek in the old family house. As the number of family members expands, the family becomes more inclusive. Dharma and Rafy are not Chinese, and Indah's baby is of mixed-race, but all of them are part of a family and of a new Indonesia that is not defined by ethnicity but by a spirit of togetherness.

A similar notion of "nationality" is also visible in Perempuan Kembang Jepun, as the three generations of an inter-ethnic family reunite: Lestari, also known as Kaguya; Matsumi, who used to be called Tjoa Kim Hwa; Maya and Higashi, who have been adopted into the family. Thus, the family in both novels serves as a new configuration of the nation on a micro level. This carries the message that future generations will no longer be identified by their ethnicity, a vision which Y.B. Mangunwijaya refers to as "post-Indonesia", where "tradition and nationalism [...] are given new meanings" and viewed through a completely different set of lenses from the ones used by our forefathers and foremothers. ${ }^{64}$

Ethnic tension is a legacy of the New Order that will possibly continue to mark the trajectory of the nation towards the future. But the end of Suharto's era has brought about some progress in terms of how Chinese-Indonesians are perceived and treated. Lan Fang and Clara Ng, both of Chinese descent, reflect on the identity issue faced by the Chinese. Lan Fang takes her readers back to the colonial period in order to demonstrate the fluidity of identity, as well as its importance for survival in a dangerous time. The female characters of her novel face dilemmas related to their identity, but each has her own way of coming to terms with it. The path towards conflict resolution taken by each of them shows that either we deny that identity in a multicultural society like Indonesia is never a fixed signifier of self, or we accept it as a fact to celebrate, as our identity undergoes a constant process of renewal. Similar options are offered by Clara $\mathrm{Ng}$, whose female characters are involved in a tug-of-war with their multiple identities, and find that the family is the most strategic locus for preserving and developing identity. Their Chineseness is preserved by the continuation of family traditions each time they celebrate the Chinese New Year, while their Indonesianess is solidified during such a celebration by the ever-expanding family that becomes more heterogeneous each year. Clara offers readers an optimistic outlook in regard to the solution to the "Chinese problem" that has dogged the nation for centuries, and particularly during the New Order period, but she is not blinded by the fact that external forces - both positive and destructive - will keep on playing a significant role in the process of defining the Chinese-Indonesian identity in post-Suharto Indonesia.

\section{REFERENCES}

Ang, Ien. 2001. On not speaking Chinese; Living between Asia and the West. London and New York: Routledge. 
Anwar, Adnan. 2002. "Kekuasaan dan dilemma etnis Tionghoa", in: Andreas Pardede, Dédé, and Masdar Farid Mas'udi (eds), Antara prasangka dan realita: Telaah kritis wacana anti Cina di Indonesia, pp. 135-154. Jakarta: Pustaka Inspirasi.

Butler, Judith. 1988. "Performative acts and gender constitution; An essay in phenomenology and feminist theory", Theatre Journal Vol. 40 No. 4 (December): 519-531.

Butler, Judith. 1990. Gender trouble; Feminism and the subversion of identity. London and New York: Routledge.

Butler, Judith. 1993. Bodies that matter; On the discursive limits of 'sex'. New York: Routledge.

Lan Fang. 2006. Perempuan Kembang Jepun. Jakarta: Gramedia Pustaka Utama.

Lie Tek Tjeng. 1999a. "'The Chinese problem' within the framework of political stabilization (1966)", in: Leo Suryadinata (ed.), Political thinking of the Indonesian Chinese 1900-1995, pp. 211-216. Singapore: National University of Singapore.

Lie Tek Tjeng. 1999b. "On assimilation (1967)", in: Leo Suryadinata (ed.), Political thinking of the Indonesian Chinese 1900-1995, pp. 217-221. Singapore: National University of Singapore.

Lim, Linda Y.C. and L.A. Peter Gosling. 1997. "Strengths and weaknesses of minority status for Southeast Asian Chinese at a time of economic growth and liberalization", in: Daniel Chirot and Anthony Reid (eds), Essential outsiders; Chinese and Jews in the modern transformation of Southeast Asia and Central Europe, pp. 285-317. Seattle and London: University of Washington Press.

Lohanda, Mona. 2002. "'Masalah Cina' dalam perjalanan sejarah Indonesia", in: Andreas Pardede, Dédé, and Masdar Farid Mas'udi (eds), Antara prasangka dan realita: Telaah kritis wacana anti Cina di Indonesia, pp. 49-76. Jakarta: Pustaka Inspirasi.

Mangunwijaya, Y.B. 1999. "Menghadapi budaya Pasca-Indonesia dan PascaEinstein", in: Agus E. Sarjono (ed.), Pembebasan budaya-budaya kita, pp. 267-280. Jakarta: Gramedia and TIM.

Mohanty, Chandra Talpade. 2003. Feminism without borders; Decolonizing theory, practicing solidarity. Durham and London: Duke University Press.

Nadj, E. Shobirin. 2002. "Problematika segregasi sosial dan upaya membangun politik kewarganegaraan", in: Andreas Pardede, Dédé, and Masdar Farid Mas'udi (eds), Antara prasangka dan realita: Telaah kritis wacana anti Cina di Indonesia, pp. 99-118. Jakarta: Pustaka Inspirasi.

Ng, Clara. 2006. Dimsum terakhir. Jakarta: Gramedia Pustaka Utama.

Spivak, Gayatri Chakravorty. 1990. The Post-Colonial critic; Interviews, strategies, dialogues. Edited by Sarah Harasyim. New York and London: Routledge.

Subiakto, Irianto. 2002. “Ketika produk hukum melegalisasi praktek diskriminasi", in: Andreas Pardede, Dédé, and Masdar Farid Mas'udi (eds), Antara prasangka dan realita: Telaah kritis wacana anti Cina di Indonesia, pp. 183-200. Jakarta: Pustaka Inspirasi. 